\title{
Çanakkale İlinde Kara Avcılı̆̆ı ve Yöre Ekosistemine Etkileri
}

\author{
Prof .Dr. Rüştü Ilgar ${ }^{1 *}$
}

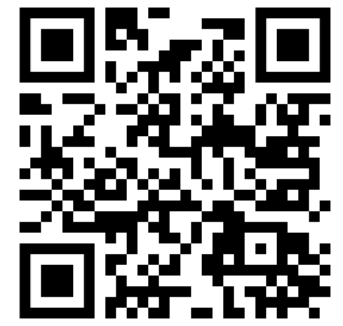

Gelis tarihi: 24.08.2020

Kabul tarihi: 04.10.2020

\section{Atıf bilgisi:}

IBAD Sosyal Bilimler Dergisi

Sayı: Özel Sayı

Sayfa: $116-132$

Yıl: 2020

This article was checked by iThenticate. Similarity Index 09\%

Bu makalede araştırma ve yayın etiğine uyulmuștur.

1 Çanakkale Onsekiz Mart Üniversitesi, Türkiye, ilgar@mail.com,

ORCID ID 0000-0002-4981-7324

* Sorumlu yazar
ÖZ

Canakkale ili ülkemizin kuzeybatısında, kendi adıyla anılan bir boğazın iki yakasında toprakları bulunan ve ülkemizin en büyük adalarından ikisine sahip bir ildir. Akdeniz ve Karadeniz iklimlerinin birbirine yaklaştığı Marmara geçiş iklimi ve kıyı kesimlerinde ise Akdeniz ikliminin özelliklerine sahip olan ilin \% 54'ü ormanlarla kaplıdır. Ayrıca farklı topografya şekillerine sahip olması il genelindeki flora ve faunanın çeșitlenmesine sebep olmuștur. Ceșitli hayvan ve bitki türlerine ev sahipliği yapması Çanakkale'nin av potansiyelini de artıran bir durum olarak karşımıza çıkmaktadır. Nitekim il göç yolları üzerinde bulunması sebebiyle ülkemizde görülen kuş türlerinin yarıdan fazlasına (\% 58) ev sahipliği yapmaktadır. Bunun sonucu olarak da il genelinde 36 adet genel avlak ve devlet avlağı, 3 adet örnek avlak, 5 adet özel avlak ve 3 adet yaban hayvanı yerleştirme sahası bulunmaktadır. İldeki avcılık faaliyetleri kapsamında kayıtlı 513 avcı, 874 adet ruhsatlı av tüfeği ile faaliyet göstermektedir. $\mathrm{Bu}$ derece yoğun av faaliyetinin yapılması il genelindeki tür çeşitliliği üzerinde baskı oluşturmakta, sürdürülebilir av turizminin uygulanmasını güçleştirmekte ve yöre ekosistemi üzerinde çeşitli tahribatlara yol açmaktadır. Bu çalışmada Çanakkale İlindeki kara avcılığı ve bölge ekosistemi üzerindeki etkileri bilimsel metotlarla ve çevreci bakış açısıyla nitel araştırma yöntemleriyle değerlendirilmiş, sonuçlar ve çözüm önerileri ortaya konulmuştur.

Anahtar Kelimeler: Avcılık, av, yaban hayatı, Çanakkale 


\title{
Land Hunting and Its Effects On The Regional Ecosystem in Canakkale Province
}

\author{
Prof. Dr. Rüştü Ilgar ${ }^{*}$
}

First received: 24.08 .2020

Accepted: 04.10.2020

\section{Citation:}

IBAD Journal of Social Sciences

Issue: Special Issue

Pages: 116-132

Year: 2020

This article was checked by iThenticate. Similarity Index 09\%

${ }^{1}$ Çanakkale Onsekiz Mart University, Turkey, ilgar@mail.com,

ORCID ID 0000-0002-4981-7324

* Corresponding Author

\section{ABSTRACT}

Çanakkale province lands take a place on both sides of a strait named after the NW part of Turkey and It is a province that has two of the largest islands of our country. Climates is Marmara transitional climate where Mediterranean and Black Sea climates converge and has the characteristics of Mediterranean climate in coastal areas and province lands $54 \%$ is coated with forests. Also have different topographical forms causes species diversity on to flora and fauna in province. The fact that Canakkale is home to various animal and plant species hosting also Çanakkale's hunting potential as a situation that increases us against emerging. Thus provincial migration routes due to being found on is hosting more than half $(58 \%)$ of bird species in our country. As a result, throughout the province there are 36 piece general hunting ground and state hunting ground, 3 piece example hunting ground, 5 piece private hunting ground and 3 piece wild animal placement areas. In the province hunting activities within registered 513 hunters, 874 piece licensed hunting rifle with a activities shows. This rating intensive hunting activity making provincewide species diversity put pressure on, making sustainable hunting tourism difficult to implement and leading to various destruction on the region's ecosystem. In this study, land hunting in Çanakkale Province and its effects on the regional ecosystem were evaluated by scientific methods as qualitative research, environmentalist wiev, finally, results and solution suggestions are presented.

Keywords: Hunting, hunt, wildlife, Çanakkale. 


\section{GİRIŞ}

Avcıllk bir canlının değişik amaçlarla diğer canlıyı, ölü veya diri olarak ele geçirmek için yürüttüğü eylemler bütünüdür. Canlılar hayatlarını devam ettirebilmek için bir enerji harcar ve bu enerjiyi de beslenerek karşılamak zorundadır. Prehistorik dönemden beri devam ede gelen avcılık, günümüzdeki gibi spor aktivitelerinin dışında tamamen hayatta kalma biçimi, hatta hayatta kalma sanatıdır (Güven ve Hergüner, 1999). Bir avcı olmak; aynı zamanda zeka ve yetenek gerektirir. İnsan beyni geliştikçe avcılık yöntem ve stratejileri de farklılık göstermeye başlamıştır. Avcıllığın tarihi insanlığın tarihine eşdeğerdir. 10000 yıldan daha uzun bir zaman önce son Buzul Çağı zirvesindeyken, insanlar avladıkları hayranların resimlerini, kullandıkları aletleri ve avlanma stratejilerini mağara duvarlarına çizimler yapmaktaydı (Davison, 1999). Kısacası avcılık insanlığın ortaya çıktığı andan bu yana sürdürülen bir uğraşıdır. İlk zamanlarda yani insanlar tarım yapmayı ve hayvanları evcilleştirmeyi henüz başaramadıkları dönemde, avcılık ve toplayıcılık ile yiyecek sorununu çözmekteydi. Hayvanların evcilleştirilmesiyle de avcılık önemini yitirmedi ve farklı lezzet arayışları bazen de evcil sürülerin yetersiz kaldığı kıtlık dönemlerinde av hayvanları gene insanlar için önemli besin kaynağını olmuştur. Bunun yanında belirtilen dönemlerde avcılık sadece et ihtiyacı için değil, aynı zamanda kürkleri için de yapılmıştır.

Türk tarihinde ise avc1lı önemli bir gelenektir. Dede Korkut hikayelerinde; av, avc1lık, av hayvanları ekonominin önemli unsurları arasında yer almaktadır (Becercan, 2010). Geniş bozkır topraklara egemen olan Türklerde avcılık her zaman ön planda olmuştur (Onay, 2015). Türk toplumunda avcılık, toplumsal yapıyı etkilemiş ve kültürü de bu boyutta değiştirmiştir. Bu nedenle avcılık aynı zamanda bir kültürdür (Cahoone, 2009). Örneğin Moğolistan, Baykal gölü ve çevresindeki Uygur duvar resimleri ve Orhun Abideleri gibi birçok yerde avcılığa dair işaretler, bulunmaktadır (Kaya, 2009). Aynı zamanda Eski Türk'lerdi avcıllk, bir nevi erkeklerin kendini gösterme biçimi ve erginleme ritüeli olarak da kabul görmekteydi (Çaya, 2015). Türk halklarının av tören ve inançları çoğunlukla birbirine benzemektedir. Örneğin Azerbaycan Türklerinin ve Sibirya Altay Türklerinin avcılık ile ilgili tören ve inançları birbirine çok benzeşmektedir. Avcının ava gitmeden önce kimseyle konuşmaması, ava temiz ve makbul günlerde gidilmesi, av tanrısına buğday, un, goğal, hayvanın iç organlarının kurban edilmesi, avın kemiklerinin gömülmesi, av etinin hamile ve loğusa kadına verilmemesi, av silahının çileye düşmekten korunması gibi kültürel ritüelleri bulunur (Celilova, 2019). Altay, Şor ve Kumandin'e göre Türklerde ava gitme öncesinden kadınla cinsel ilişkiye girilmez (Potapov, 2012). Yakın tarihte ise Osmanlı hükümdarları ve devlet yönetimindeki şahısların savaşlara hazırlık, dinlenme, eğlenme, bireyler arasındaki diyaloğun gelişmesi, denetleme amacıyla av partileri düzenlemesi oldukça önemlidir (Yarc1, 2009). Kısacası avcılık Türk toplumunda bir yaşam biçimi haline gelmiştir (Büyükarıkan, 2018).

Avcılık, silah teknolojisindeki gelişmelerle tarih boyunca bazı değişikliklere uğramıştır. Taş devrinde insanlar kesici alet olarak obsidiyen taşını kullanmaktaydı. Bir dış püskürük kayaç olan obsidiyen kırılarak bir tarafı oldukça keskin bir materyal haline dönüşür. İnsanlar bu yönünden faydalanarak mızrak, bıçak, ok gibi av aletlerini bu taş ile yapmıştır. Metalik madenlerin bulunup işlenmeye başlamasıyla gelişen silah teknolojisi avcıllğg da etkilemiş, keskinliği kısıtlı olan obsidiyenin ölümcül hasar verme olasılığının düşüklügüne karşılık metalden yapılan kesici, delici aletlerin av hayvanını daha kolay öldürebilmesi avcılı̆̆ kolaylaştıran bir gelişme olmuştur. Bir sonraki aşamada ise barutun ateşli silahlarda kullanılması ile avcıllkta yeni bir devrim olmuştur. Artık av yapmak kolaylaşmış, eski zamanlarda iri ve güçlü hayvanları avlamak büyük cesaret gerektirirken artık tek bir parmak hareketiyle bu hayvanların öldürülebilmesi mümkün hale gelmiştir (Dillinger, 2012).

Geçmişten günümüze avcılık hem Türklerde, hem de dünyada fonksiyonel olarak boyut değiştirmiş, askeri eğitim ve boş zaman aktivitesinin önemli rekreasyon faaliyeti olmuştur. Günümüzde yiyecek sorununun ortadan kalkmış olmasına rağmen avcıllğın devam etmesi, sportif turizm faaliyeti olarak görülmesiyle ilgilidir. Hatta öyle ki Türkiye'deki av faaliyetlerine yapılan harcamaların toplam turizm gelirlerine oranı yaklaşı \% 7 düzeyindedir (Özer, 2020). Avcılık turizmini tetikleyen etmen sadece rekreasyonel faaliyet olmayıp aynı zamanda farklı lezzetlerin cazibesi, kürkleri ve ürünlerinin (diş, yağ, boynuz, gaga, kürk, dolgu maddesi olarak vücutları vb..) ekonomik değeri de etkili olmaktadır.

Bunun sonucunda yasa dışı avcılık dünyanın her yerinde yaygın olarak hala devam etmekte ve ekosisteme ciddi zararlar vermektedir. Avcılık yapılmasa dahi insanoğlunun diğer faaliyetleri de (yeni tarım alanlarının açılması, sanayi alanlarının ve şehirlerin genişlemesi vb.) av hayvanları üzerinde ciddi 
baskılar oluşturmaktadır. Doğal yaşam alanlarının kısıtlanması ile sık sık insanlarla karşı karşıya gelmeye başlayan bu hayvanlar yiyecek sıkıntısı çektikleri için de insanlara yakın olmayı tercih edebilmektedir. Nitekim çöplükler ve tarım alanları bazı av hayvanları için çekici olabilmektedir. İnsan kaynaklı faktörler, kentleşme, meraların imara ve kültürel arazilere dönüştürülmesi, aşırı otlatma, başıboş köpekler, sulak alanlara müdahaleler, yanlış ormancılık faaliyetleri, oto yollar ve tren hatları, aşırı ve kaçak avc1lık) bu çalılara zarar vermektedir (Ünal, 2019). İnsanların ekosisteme etkileri bununla da sınırlı değildir. Avcılık sonunda birçok hayvanın bilinçsizce öldürülmesi bazı türlerin soyunu tükenmekte bazılarının popülasyonlarında ciddi azalmalara yol açmıştır.

$A v$ ve yaban hayatı yönetiminin temelinde canlıları korumak yatar. Türkiye Batı Paleoarktik bölge içinde çok çeşitli coğrafi yeryüzü şekilleri, iklimi ve bitki örtüsü nedeniyle çok zengin bir biyolojik çeşitliliğe ve çok farklı ekosistem özelliklerine sahiptir. Örneğin Bütün Avrupa'daki toplam bitki türü 12.000 iken, Türkiye'de yaklaşı 9.000-10.000 tür yer almaktadır (Ilgar, 2018). Bu zenginliğe rağmen yapılmış olan çalışmalarda Türkiye'deki hayvan varlığının ciddi bir yok olma tehdidi ile karşı karşıya olduğu ifade edilmektedir (Demirsoy, 2007). Korumanın temelinde onları tanımak vardır. Nitekim yaban hayatı yönetimi, avlanma ve avcılıkla doğrudan ilişkilidir (Oğurlu, 2008). Bu nedenle kara av hayvanlarını koruyabilmek için onları tanımamız, ekolojik ve biyolojik özelliklerini bilmemiz gerekmektedir. Kara av hayvanlarının karakterlerinin yanında diğer özelliklerini (üreme, beslenme vs.) araştırmak, bunların düzenli kayıtlarını tutmak büyü bir önem taşımaktadır. Doğadaki canlıların farklı beslenme ve yaşama alışkanlıkları vardır. Besin kaynakları ve iklim özelliklerine göre kara av hayvanlarının dağılışları değiştirmektedir. Optimum yaşam şartlarını bulduklarında geniş habitatlar oluşturarak varlıklarını devam ettirebilmektedirler. Bazıları ise bulundukları habitatları mevsimsel değişiklikler ve yiyecek kıtlı̆̆ı, üreme gereksinimi nedeniyle değiştirmekte yani besin aramak ve üremek için göç etmektedir. Değişmeyen göç yolları üzerindeki mevsimsel göç hareketleri binlerce yıldır sürdürüle gelmektedir. Avcılık faaliyetlerinin sürdürülebilir şekilde yapılması için, ekosistemde gerek yerleşik, gerekse göç yoluyla gelmiş canlı popülasyonuna zarar vermeden gerçekleştirilmesi önemlidir.

\section{MATERYAL ve METOD}

Çalışmada materyal olarak literatür taraması yapılmış, konu hakkında yazılı kaynaklar (makale, tez, bildiri vs) incelenmiş, Orman Bölge Müdürlüğü'nün raporları, Çanakkale İl Çevre Durum Raporları, ve MAK (Merkez Av Komisyonu) kararları; ilde yaşayan avcıların görüşleri çalışmanın materyalini oluşturmuş̧tur. Araştırmada nitel araştırma yöntemlerinden durum betimlemesi yöntemi kullanılmıştır. Ayrıca çalışma avcılarla yapılan mülakat sonuçları ile desteklenmiştir. Bu çalışmada da bilinçsiz avcılı̆̆ın Çanakkale ilinde sürdürülebilir kara avcılığı üzerindeki etkileri tartışılmıştır.

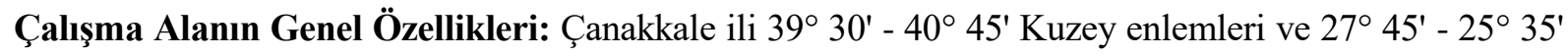
Doğu boylamları içinde yer alır (Şekil 1). Türkiye'nin kuzeybatısında, Marmara Bölgesi'nin ise güneybatısındadır. Çanakkale ili izdüşümü alanı $9.950 \mathrm{~km}^{2}$, gerçek alan $10.347 \mathrm{~km}^{2}$, yüz ölçümü 9.737 $\mathrm{km}^{2}$ 'dir. Bu boyutuyla Çanakkale İli, Türkiye topraklarının yaklaşık \% 1,3'ünü kapsamaktadır. Türkiye tarımsal üretim değerindeki payı ise \% 1.97'dir (Tarım ve Orman Bakanlığı, Çanakkale İl Müdürlüğü, 2019). Çanakkale 993.318 hektarlık arazinin; 525.580 hektarı ormanlık ve fundalık arazi 331.633 hektarı işlenebilir arazi, 104.440 hektarı tarım dışı arazi ve 31.665 hektarı çayır-mera arazisinden oluşmaktadır. 12 ilçesi, 21 bucağı, 577 köyü, 18 beldesi bulunan ilin toplam yerleşim yeri alanı 8881.741 dekardır. 


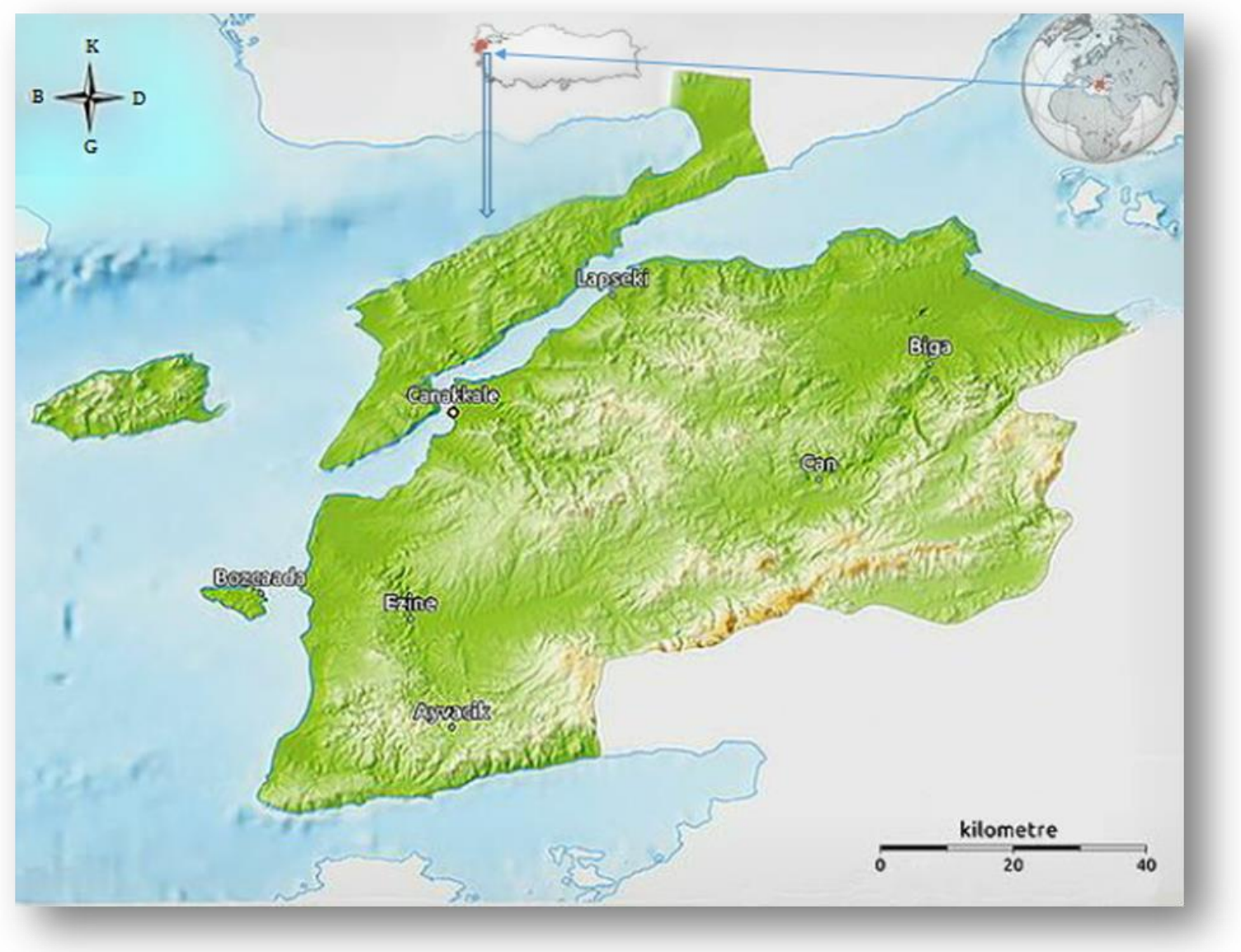

Şekil 1. Çalışma alanın lokasyonu

Çanakkale il nüfusu 542.157'dir. Bu nüfusun 272.097'si erkek ve 270.060'1 kadınlardan oluşmaktadır (erkek \% 50,19'a, kadın \% 49,81'dir). Nüfus artış oranı Türkiye ortalamalarının üzerinde seyretmektedir (Şekil 2). Artış oranı \%o 19,1 düzeylerinde seyretmesine rağmen bu artışın ana nedeni dışardan gelen göçlerdir. Bunu doğrulayan etmen 1,53'lük toplam doğurganlık hızıyla Türkiye'nin en az doğurganlığa sahip illerinden biri olmasıdır (Şahin, 2006). Aynı zamanda Çanakkale ortalama hane halk1 büyüklüğü bakımından 2,7 kişi ile Türkiye'nin hane halkı en düşük ilidir (TUIKK, 2019). Dolayısıyla nüfus artış hızında istikrar bulunmaz ve sürekli dalgalanmalar görülür.

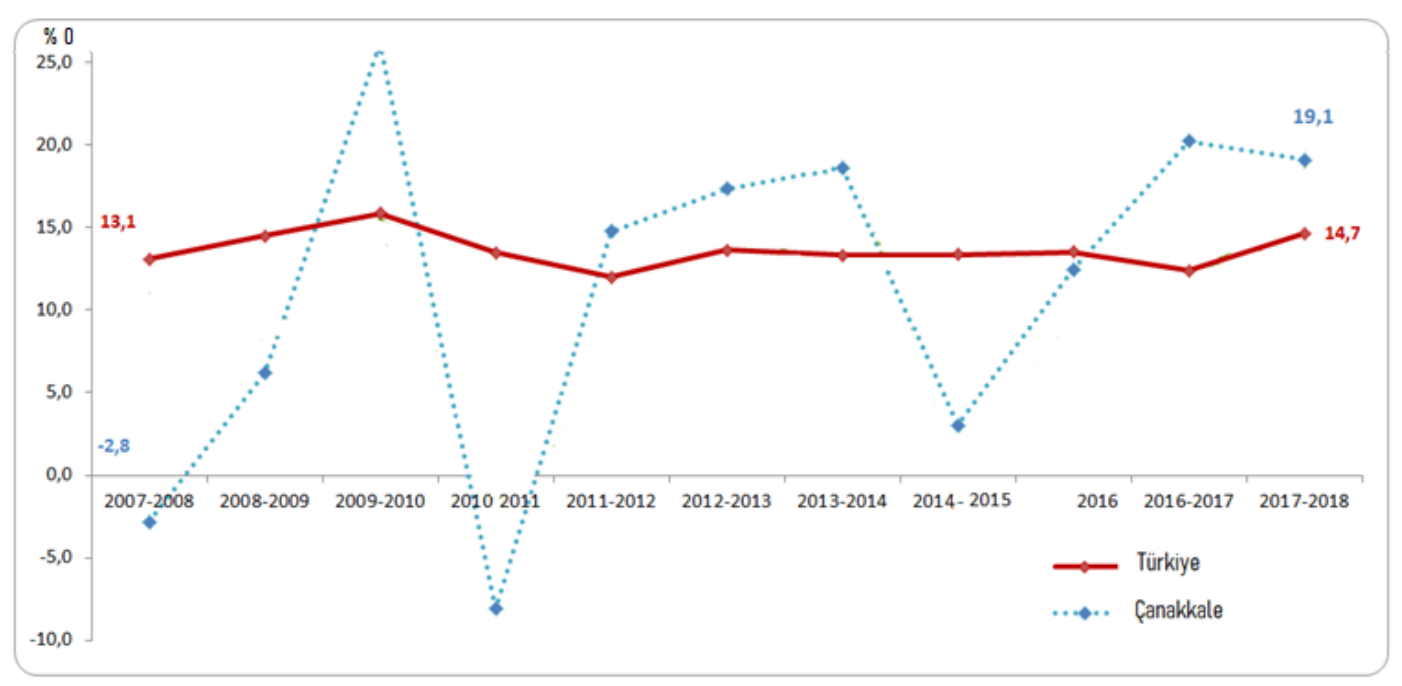

Şekil 2. Çanakkale'nin ve Türkiye'nin nüfus artış oranları 
Toplam il nüfusunun \% 43.7'si belde ve köylerde yaşamaktadır. Çanakkale ili yaşlı nüfusun yoğun olduğu bir ildir. Çanakkale ili ülke nüfusunun \% 0.66 'sını, yüzölçümünün ise \% 1.29'unu bulundurmaktadır. Nüfusun \% 12.7'si 65 yaş ve üzerindedir. Nüfusun \% 16.4'üde 15 yaş ve altındadır (TUIK, 2019).

Çanakkale ilinin toprakları, genellikle engebeli (dağ ve tepelerle) jeomorfolojik görünüme sahiptir. İl toprakları vadilerle parçalanmıştır. En yüksek rakıma 1767 m ile Kaz Dağında ulaşılır. Kaz dağları birçok yönden doğal yaşamın ve biyoçeşitliliğin temel kaynaklarından birini oluşturan çok özel bir coğrafi mekândır. Çanakkale ve çevresinin yapısal özelliklerini, Miyosen başlarında oluşan tortulanma çanağını oluşturan Miyosen formasyonlarının kıvrılıp, kırılmasına neden olan Üst Miyosen ve Pliyosen tektonik hareketleri belirlemiş̧ir. Çanakkale tortulanma çanağ dolmaya başlamış, çanak ortalarında oluşan kumlu-karbonatlı çökeller, jipsli lagünler tortullar ile oluşumunun son evrelerine erişirken; havza kenarlarındaki akarsu çökelleri tüm bölgeyi kapsayacak biçimde yaygınlaşmıştır (Erol, 1985). Çanakkale ve çevresinde farklı jeolojik dönemlerde oluşmuş, farklı kayaç grupları yüzeylenmektedir. En yaşlı kayaçları ağırlıklı olarak metamorfiklerden oluşan Paleozoyik yaşlı temel oluşturur. Kazdağı grubu olarak adlandırılan bu eski temeli oluşturan unsurlar, Permiyen öncesi yaşlı kayaçlar da bulunur (Ercan, 1996).

Çanakkale ve çevresinde Oligosen yaşlı bir volkanizma aynı yaştaki çökel birimlerine eşlik etmiştir. Andezit, dasit, trakiandezit, ve riyodasit bileşimde olan ve yeni bir volkanik evre ile meydana gelen kayaçlar geniş bir alan kaplarlar ve volkanizma tüm Oligosen boyunca devam etmiştir. Oligosen sonunda Biga ve Gelibolu Yarımadalarında önemli bir aşınma devresi olmuş, bu nedenle karasal, gölsel ve sığ denizel nitelikte Miyosen çökelleri ve volkanitleri çok farklı eski kaya birimleri üzerinde yer almışlardır. Miyosen oluşukları birbirinden farklı özellikler gösteren iki evreye ayrılmaktadır (Siyako ve di.̆., 1989).

\section{BULGULAR}

Çanakkale ilinin en önemli özelliklerinden birisi Şekil 3’te görüleceği üzere il yüz ölçümünün yarısından fazlasının ormanlarla kaplı olmasıdır. Bu özelliği yaban hayatına önemli habitat kaynakları oluşturmuşstur.

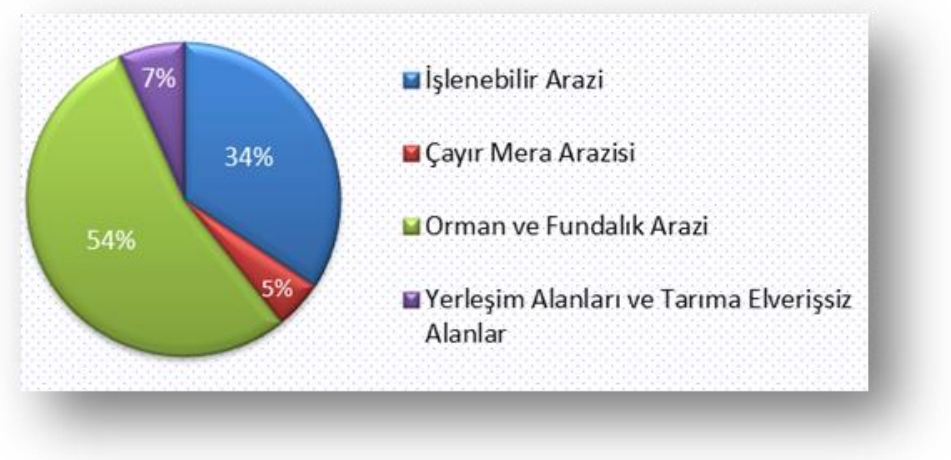

\section{Şekil 3. Çanakkale arazisinin kullanım alanlarına göre dağıllı̧̧ı}

Kaynak: Tarım ve Orman Bakanlığı Çanakkale İl Müdürlüğü 2019 verileri.

Çanakkale İli zengin orman varlığı, sahip olduğu iklim özellikleri ve göç yolları üzerinde yer alması nedeniyle zengin bir yaban hayatına sahiptir. İlin doğal dokusunun da fazla tahrip olmamış olmaması bu zengin flora ve faunanın günümüze kadar varlığını koruyabilmesinde baş aktörlerdendir. Ayrıca topografya şekillerinin çeşitlilik göstermesi, deniz seviyesinden yükseklere kadar farklı yükselti basamaklarının varlığı ve orman dokusu yöredeki yaban hayatını destekler niteliktedir (Kantarcı, 1997).

Çanakkale İli göç yolları üzerinde bulunduğu için Türkiye'nin sahip olduğu kuş türlerinin \% 58'ine ev sahipliği yapar, Kazdağı Milli parkının il sınırlarında yer alması nedeniyle çeşitli memeli türlerine sahiptir. Sahada en çok rastlanılan kuş türlerine bülbül (Luscinia megarhynchos), doğan (Falco 
peregrinus), kartal (Aquila chrysaetos), şahin (Buteo buteo), keklik (Perdix perdix), martı (Larus Ganus) örnek gösterilebilir. Memeli türlerinde ise ayı (Ursus arctos), çakal (Canis aureus), tilki (Vulpes vulpes), kurt (Canis lupus), domuz (Sus scrofa), sansar (Martes fiona), tavşan (Lepus europaeus) en sik rastlanılan türlerdendir (http://www.canakkale.com.tr/tr/sehri-yasa/flora-fauna 31.05.2017).

\section{Çanakkale'de Avcılı̆̆ı Yapılan Bazı Hayvan Türleri ve Genel Özellikleri}

Çanakkale'de avcılığı yapılan türler doğada serbest olarak yaşamaktadır. Bunların bir kısmı yaşam alanına bağlı olduğu halde, bir kısmı mevsimlere göre uzun ve kısa mesafeler dahilinde göç eder. Göçmen kuşların Mart ve Nisan aylarında yöreye olan gelişleri ve üreme dönemlerine rastlayan yuvalanmaları gözlemlenmektedir (Çalışkan ve diğg, 2013). Bunların en belirgin özellikleri yabani oluşları ve yaşam ortamlarında sürekli hareket halinde oluşlarıdır.

Çamurcun (Anas crecca): Boyları 34-38cm, kanat açıklı̆̆ $53-59 \mathrm{~cm}$, ağırlıkları 300-350gr arasında değişen ördeğin küçük bir türüdür. Sazlık alanlarda, durgun veya yavaş akan tatlı su kaynaklarında, toprak tabanlı küçük göllerde görülür. Erkeklerinin başı kahverengi, göz çevresi mavi, yeşil renklidir. Dişilerin gögüs kısmı açık renkli sırt ve kanat kısımları grimsi renktedir. Böcekler, tahıllar, çayırlar ve tohumlar diyetini oluşturur. Ülkemizde Şekil 4'te görüldüğü gibi Marmara, Ege, Akdeniz, Batı ve Orta Karadeniz, İç Anadolu ve Güneydoğu Anadolu bölgelerinin tamamında, Doğu Anadolu Bölgesi'nin Yukarı Fırat Bölümü'nün güneyinde ve Doğu Karadeniz kıyı kuşağında dağılış göstermektedir (http://www.milliparklar.gov.tr/kitap/64/?sflang=tr\#p=10 Erişim Tarihi: 03.06.2017).

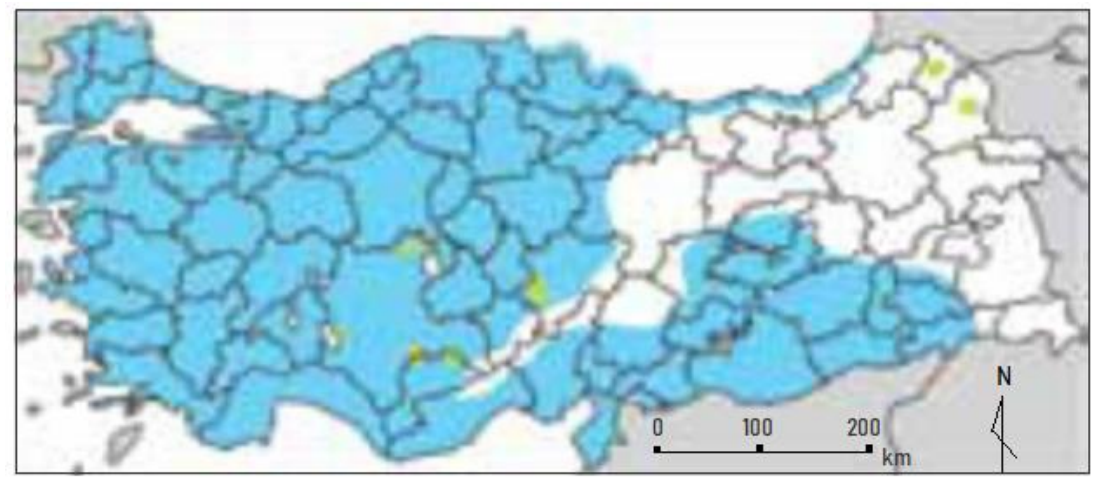

Şekil 4. Çamurcun (Anas crecca) dă̆ıllış haritası

Yeșilbaș (Anas platyhynchos): Boyları 50-60 cm, kanat açıklığı 81-95cm, ağılıkları 1-1,2kg arasında değişen neredeyse her türlü sulak alanda bulunabilen yaygın bir ördek türüdür. Erkekler parlak yeşil başlı, dişiler gri renklidir ve uçarken kanadında parlak mavi bir panel görülür. Hem bitkisel hem de hayvansal besinleri kullanır. Şekil 5'te görüldüğü gibi Doğu Anadolu Bölgesi'nin yüksek rakımlı yerleri ve Doğu Karadeniz Dağları hariç ülkemizin her yerinde görülür (http://www.milliparklar.gov.tr/kitap/64/?sflang=tr\#p=22 03.06.2017).

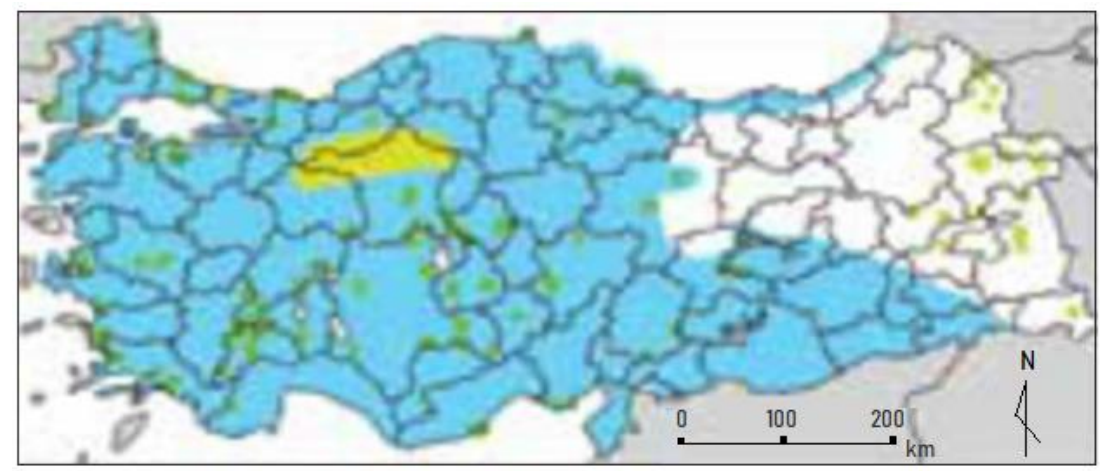

Şekil 5. Yeşilbaş (Anas platyhynchos) dağıllış haritası 
Elmabas Patka (Aythya ferina): Boyları 42-49cm, kanat açıklıkları $67-75 \mathrm{~cm}$, ağırlıkları 0,9-1kg arasında değișen bu tür bitki bakımından zengin ve $6 \mathrm{~m}$ 'den derin olmayan sulak alanlarda bulunur. Çoğunlukla göllerde, ancak özellikle kışın firtınalı günlerde limanlarda sıkça görülür. Erkeklerde baş parlak kahverengi, gerdan siyah, vücut gri ağırlıklı, dişilerde ise baş ve gerdan soluk kahverengi ve gövde kahverengimsi gri ağırlıklıdır. Sucul ve su çevresi bitkilerin yaprak, gövde ve kökleri ile ayrıca sudaki böcekler, amfibiler ve küçük balıklarla beslenir. Ülkemizdeki dağılışı çamurcun ile benzerlik gösterir.

Tepeli Patka (Aythya figula): Boyları 40-47cm, kanat açıklıkları $65-72 \mathrm{~cm}$, ağırlıkları $0,7-0.8 \mathrm{~kg}$ arasında değişen bu tür çoğunlukla büyük tatlı su göllerini tercih eder. Ayrıca lagünler gibi korunaklı sahiller, acı iç sular ve bazen limanlar ve akarsu ağızlarında bulunur. Erkeklerin başı, boynu, gerdanı sırtı ve kuyruğu siyahtır. Ayrıca başında enseye doğru uzanan uzunca tüyleri vardır. Midyeler, salyangozlar, sucul böcekler ve sucul bitkilerle beslenir. Ülkemizde Şekil 6'da görüldüğü gibi Marmara Bölgesi, Ege Bölgesi, İç Anadolu Bölgesinin orta ve batı kesimleri ile Karadeniz kıyı kuşağında dağılış gösterir (http://www.milliparklar.gov.tr/kitap/64/?sflang=tr\#p=22 03.06.2017)

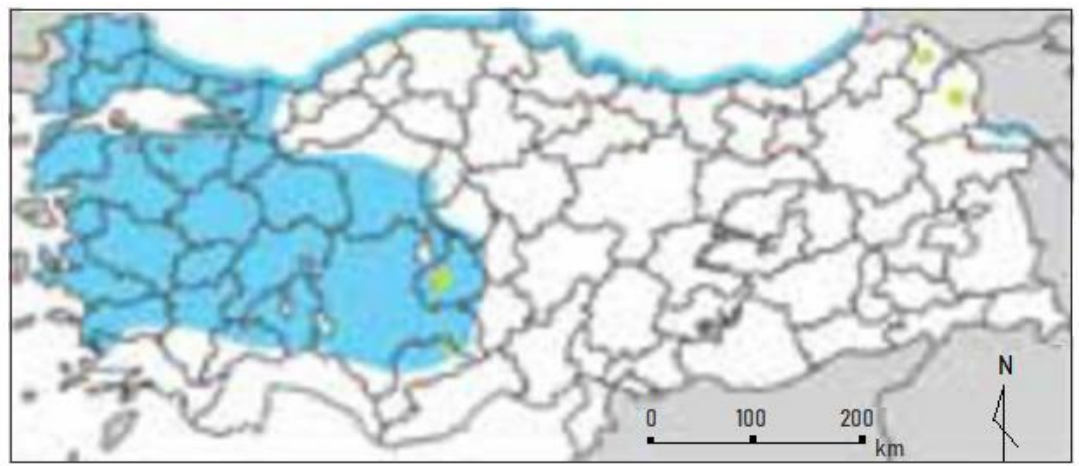

Şekil 6. Tepeli patka (Aythya figula) dağgllı̧ haritası

Kinalı Keklik (Alectoris Chukar): Boyları 32-35cm, kanat açıklı̆̆ı 47-52cm, ağırlıkları 400-800gr arasında değiş̧en bu tür kayalık ve sarp arazileri sever. Ayrıca kurak ve yarı kurak alanlarında, çalılık, otlu yamaçlar ve ekili alanlarda yaşar. Ağırlıklı olarak otsu bitkilerin tohumları ile beslenen bu tür böcek ve çekirge ile de beslenir. Şekil 7'de görüldüğü gibi Karadeniz sahil kesimi hariç ülkemizin her yerinde yaygın olarak görülür (http://www.milliparklar.gov.tr/kitap/64/?sflang=tr\#p=30 03.06.2017)

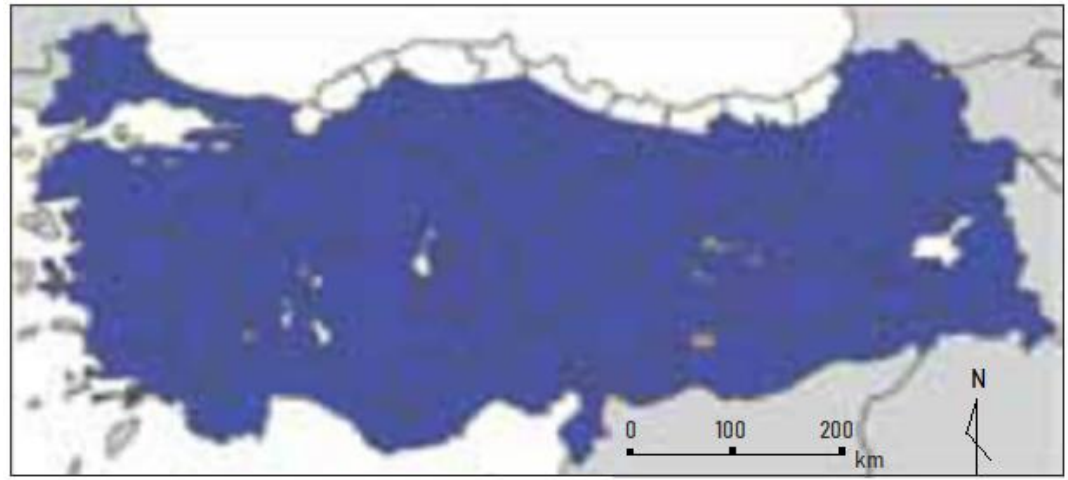

Şekil 7. Kınalı keklik (Alectoris chukar) dă̆gllı̧ haritası

Bıldırcın (Coturnix coturnix): Boyları 16-18cm, kanat açıklığı 32-35cm, ağırlıkları 90-140gr olan bu hayvan karasal bir türdür. Yüksek otlu açık alanlar, tahıl tarlaları yuvalanma alanlarıdır. Renkleri ile ortam rengine çok iyi uyum sağladıkları için görülmeleri oldukça zordur. Genelde bitki tohumlarıyla beslenseler de böcekler ve çekirgelerle de beslenirler. Şekil 8'de görüldüğü gibi Güneydoğu Anadolu Bölgesi'nde küçük bir alan dışında ülkemizin her yerinde görülürler http://www.milliparklar.gov.tr/kitap/64/?sflang=tr\#p=36 03.06.2017) 


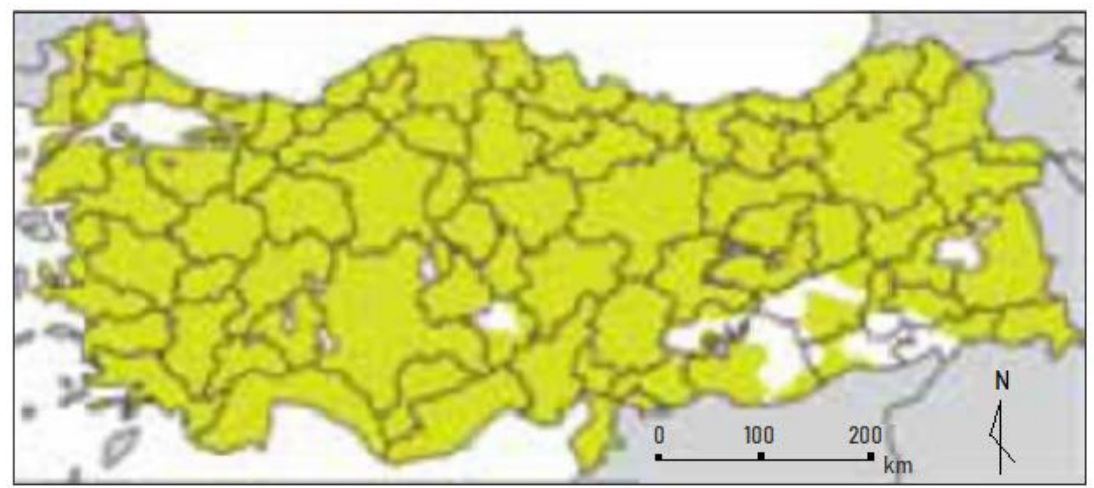

Şekil 8. Bıldırcın (Coturnix coturnix) dağılış haritası

Culluk (Scolopax rusticola): Boyları 33-38cm, kanat açıklığı 55-65cm, ağılıkları 260-300gr arasında olan bu tür zemini humus ve toprak solucanı bakımından zengin ormanları tercih eder. Ayrıca böcek larvaları, midye, tohum meyve tahıl gibi besinleri tüketirler. Şekil 9'da görüldügü gibi ülkemizin kıyı kuşağı boyunca ve Ege Bölgesi'nin tamamında görülür (http://www.milliparklar.gov.tr/kitap/64/?sflang=tr\#p=22 03.06.2017).

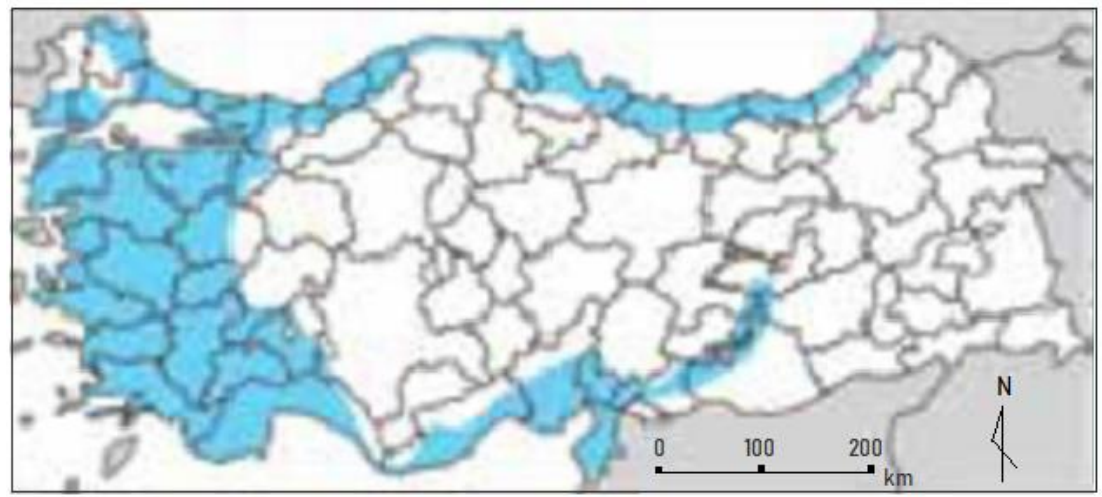

Şekil 9. Çulluk (Scolopax rusticola) dağılış haritası

Üveyik (Streptopelia turtur): Boyları 25-27cm, kanat açıklığı 49-55cm, ağırlıkları 130-150gr olan bu tür orman kenarları, çalılık alanlar, bahçe ve tarlalar gibi açık alanlarda görülür. Çoğunlukla tohum yemesine rağmen bazen böceklerle de beslenir. Ülkemizdeki dağılışı Şekil 10'da görüldüğü gibi bildırcın büyük oranda paralellik göstermektedir (http://www.milliparklar.gov.tr/kitap/64/?sflang=tr\#p=22 03.06.2017).

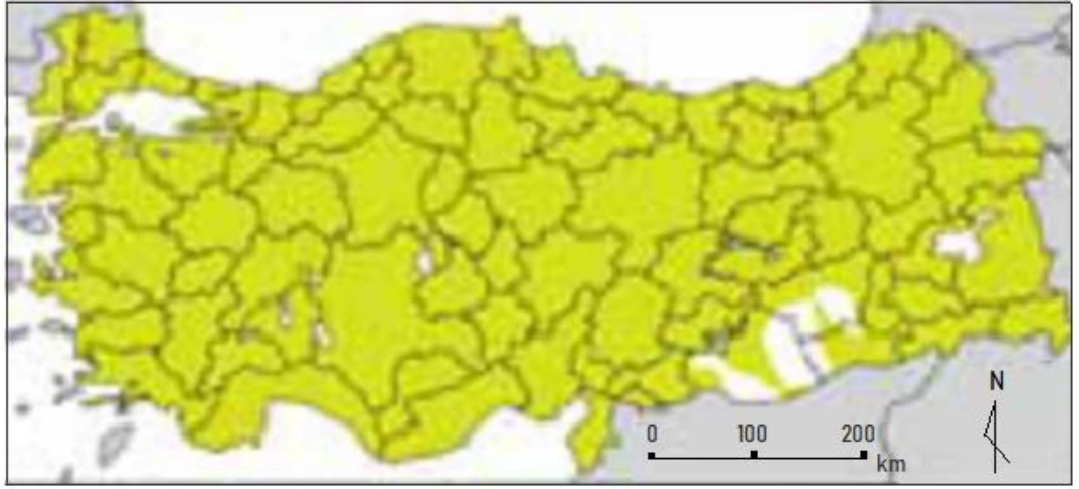

Şekil 10. Üveyik (Streptopelia turtur) dăğllı̧ haritası

http://www.milliparklar.gov.tr/kitap/64/?sflang=tr\#p=48 (03.06.2017)

Yabani Tavșan (Lepus europaeus): Boyları en fazla 45-85 cm arasında değişir. 2,5-7 kg arasında ağırlığa sahiptir. Türkiye'nin her yerinde görülür. Sabahın erken saatlerinde veya çoğunlukla gece 
aktiftir. Gelişmiş koku alma ve duyma yeteneğine sahip bir memelidir (http://www.milliparklar.gov.tr/kitap/64/?sflang=tr\#p=22 03.06.2017). Dağılış1 Şekil 11'deki gibidir.

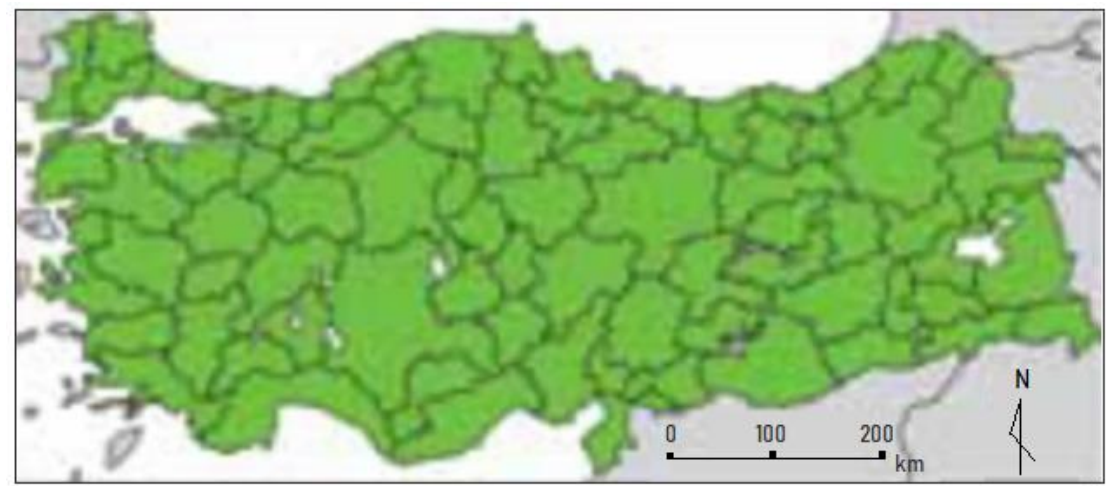

Şekil 11. Yaban tavşanı (Lepus europaeus), tilki (Vulpes vulpes), kaya sansarı (Martes fiona) ve domuz (Sus scrofa) dă̆ıllış haritası

Cakal (Canis aureus): Boyları 110-125cm, ağırlıkları 8-15kg arasında olan bu tür rengi grimsi, altın sarısı ve tonlarında olan memeli bir hayvandır. Türkiye'de Şekil 12'de görüldüğü gibi en çok kıyı bölgelerindeki sık ormanlık ve çalılarda, Iğdır ve Güneydoğu Anadolu'nun çukur yerlerinde yaşar ve iç bölgelerde görülmez (http://www.milliparklar.gov.tr/kitap/64/?sflang=tr\#p=22 03.06.2017).

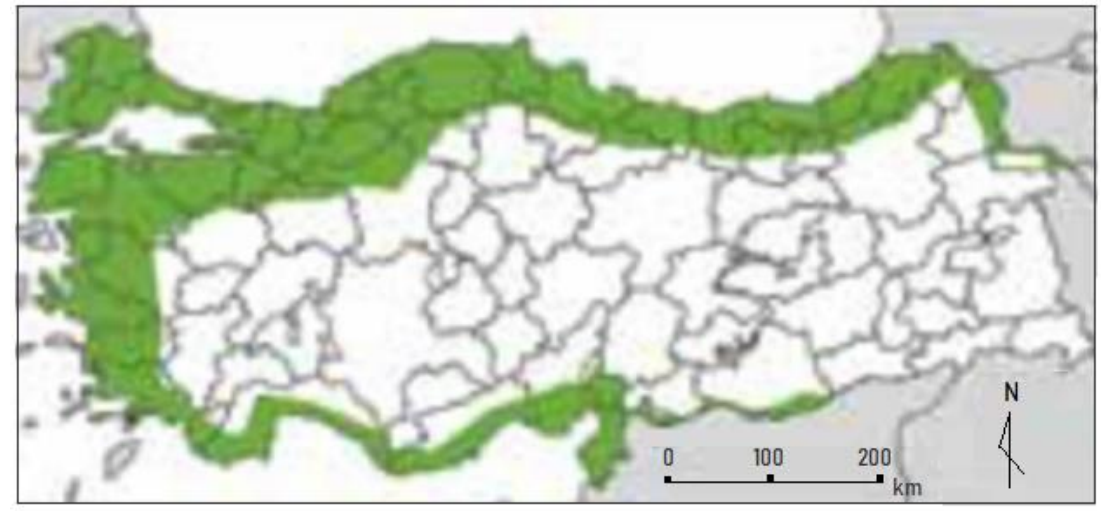

Şekil 12. Çakal (Canis aureus) dağılış haritası

Tilki (Vulpes vulpes): Boyları 50-90 cm ağırlıkları 3-10 kg arasında değişen bu türün kulak arkası siyah veya koyu kahverengi olup vücudu silindirik bacakları kısadır. Denizden 2500 m'ye kadar çalılar, ormanlar, bozkırlar, açık araziler, şehir ve köy civarlarında bulunur. Çok çeşitli küçük hayvanları avlarlar leş ve meyve ile beslenirler. Ülkemizin hemen her yerinde görülebilirler (Şekil 13).

Kaya Sansarl (Martes fiona): Boyları 38-60cm, ağırlıkları ise 0,9-2,1kg arasında değişen bu türün bacakları kısa, kuyrukları uzun ve sık kıllıdır. Kayalık ve taşlıklarda, orman kenarlarında ya da düz olmayan karışık ormanlarda yaşar. Yerleşim alanlarında da görülebilen bu tür $3000 \mathrm{~m}$ yüksekliğe kadar ülkemizin her yerinde görülür.

Yaban Domuzu (Sus scrofa): Boyları 100-180cm, ağırlıkları 150-200 kg olan bu türün erkekleri daha büyüktür. Kaba sert kıllı kürkü koyu griden kahverengiye kadar değişir. Ülkemizin hemen her yerinde geniş yapraklı ve karışık ormanlar başta olmak üzere uygun bitki örtüsüne sahip her yerde yaşar. Ancak su ihtiyacı nedeniyle sazlık, sık çalılık ve kamışla çevrili bataklık, göl ve akarsu kenarları ile çalıların olduğu meralarda görülür (http://www.milliparklar.gov.tr/kitap/64/?sflang=tr\#p=22 03.06.2017).

Yasa dışı avcılık çeşitli şekillerde yapılmaktadır. Bunlardan ilki gece avcılığıdır. Gece avcılığında yüksek 1şık değerine sahip fenerler av hayvanının gözüne tutularak adeta kör olmuş̧̧asına hayvanın kaçamaması sağlanmakta, sabit bir hedef olarak av hayvanının vurulması kolaylaşmaktadır. 
İkinci olarak çoğunlukla yeni biçilmiş tahıl tarlaları tercih edilerek bıldırcın (Coturnix coturnix) ve üveyik (Streptopelia turtur) avında bu kuşların sesinin verildiği teyp kullanılmaktadır. Geceden sabaha kadar bu teypleri sürekli ses yayarak ortamdaki kuşlar ise bu sesleri duyarak teybin etrafına toplanmaları sağlanır. Birçok av hayvanının bir araya toplanmasıyla önceden pusuya yatmış olan avcılar tek seferde birçok av hayvanını kolayca avlama şansına sahip olur.

İlde ruhsatsız tüfekle, avlanma belgesine sahip olmayan avcıların yasa dışı avlanma faaliyetleri nedeniyle doğal ortamda büyük tahribatlar oluşmakta bunun sonucunda ekosisteminde çok olumsuz (av hayvanlarının sayı ve tür çeşitliliğinde aşırı kayıplar gibi) etkiler oluşabilmektedir.

Çanakkale ilindeki çeşitli avcılık-atıcılık kulüpleri, ihtisas spor kulübü olarak faaliyet göstermiştir. Bunları şu şekilde özetlemek mümkündür.

Çanakkale Avcılık-Atıcılık İhtisas Kulübü: İki çeşit avcılık yapılmaktadır. Keklik (Alectoris Chukar) tavşan (Lepus europaeus ve sürek avı (yaban avı). Sürek avı önceleri serbest iken şu an jandarma denetimde gerçekleştirilmektedir. Eğer yapılan tarım faaliyetine yaban hayvanları zarar verirse avına izin vardır. Yivsiz silah kullanımı mecburidir. Otomatik, çift veya tek kırma silahlar kullanılır. Otomatiklerde $2+1=3$ kuralı vardır ve bu Çanakkale'de uygulanmaktadır.

Gökçeada Avcılık-Atıcılık Derneği: Burada yerli hayvan olarak keklik (Alectoris Chukar) ve tavşan (Lepus europaeus) avlanmaktadır. Göç eden hayvanlar sığırcık (Sturnus vulgaris), çulluk (Scolopax rusticola), ördek (Anas platyhynchos), rastlanırsa kaz (Anser anser) ve karabakal (Turdus merula) da avlanmaktadır. Özellikle avlanılan yerler; Uğurlu, Şirinköy, Eşelek, Kuzulimanı, Kokina, Kapıkaya'dır. Adanın \% 50'si avlanmaya kapalı alandır. Özellikle avlanmanın yasak olduğu yer Kuzulimanı-Karaköy arasıdır. Derneğin 70 üyesi vardır. 25 Ekim'de av sezonu açılmaktadır. Yazın dışarıdan 2500 avcı gelmektedir. Başlıca sorun ise hem yasak alanda avlanma yapılması, hem de limit aşımı (günlük 2 keklik (Alectoris Chukar), 1 tavşan (Lepus europaeus)) bulunmaktadır (Rasgele Dergi,1997).

Bayramiç Avcıllk-Atıcılık İhtisas Derneği: Çalışma alanında tavşan (Lepus europaeus), keklik (Alectoris Chukar), ördek (Anas platyhynchos), yelve (Emberiza clrlus), domuz (Sus scrofa), çakal (Canis aureus), kurt (Canis lupus) av1 yapılmaktadır. Ay1 (Ursus arctos) ve karaca (Capreolus capreolus) avı yasaktır. Derneğin 385 üyesi vardır. Avcılık belgesi olanlar 200 kişidir. Olmayanların da ruhsatlı silahları yoktur. Yivsiz, yerli ve yabanc1 av tüfekleri kullanılır. Genelde otomatik silahlar kullanılır. 5'li ve 8'li gibi ancak burada 2+1=3 kuralı uygulanmamaktadır.

Gümüşçay-Biga Avcılık-Atıcılık Kulübü: Yörede bıldırcın (Coturnix coturnix), ördek (Anas platyhynchos), tavşan (Lepus europaeus), yelve (Emberiza clrlus avı yapılmaktadır. Domuz (Sus scrofa), geyik (Cervus elaphus), karacanın (Capreolus capreolus) avı yoktur. Kulübün 200-250 civarında üyesi vardır. Bunların 40 tanesinin avcılık belgesi mevcuttur. Yivsiz av tüfekleri kullanılmaktadır ve $2+1=3$ kuralına uyulmaktadır. Ece gölü kenarları, dere ve çaylarda avcılık yapılmaktadır. Jandarmanın sıkı denetiminden dolayı usulsüz avcılık engellenmiştir.

Biga Avcıllk-Atıcıllk Kulübü: Yörede ördek (Anas platyhynchos), tavşan (Lepus europaeus), bıldırcın (Coturnix coturnix), üveyik (Streptopelia turtur), domuz (Sus scrofa), keklik (Alectoris Chukar), özellikle çulluk (Scolopax rusticola) avı yapılmaktadır. Silah sahibi 7000 kişi vardır. Ancak bunlardan köyler ile birlikte 2000 civarındakilerin belgesi mevcuttur. Yivsiz, otomatik, tek kırma, çift kırma silahlar kullanılır. 2+1=3 kuralına uyulmaktadır. Otomatiklerde 5'li ve 8'li olanlar içindeki takoz ile sinırlandırılır ve $2+1=3$ 'e uydurulur. Sınırlandırılmazsa ceza alınır. Kaçak avcılık yapılmaktadır. Gündüz teyp ile güme avcılığı, sulak alanlarda göç esnasında ve gece yapılmaktadır. Genelde göl boyları, deniz boylarında avcılık yapılmaktadır.

Tablo 1. de görüldüğü gibi Çanakkale ilinde 1'i Gökçeada'da, 6's1 Gelibolu'da olmak üzere 29 adet devlet avlağı; 1'i Bozcaada'da, 3'ü Gelibolu'da olmak üzere 18 adet genel avlak alanı; 1'i Gökçeada'da olmak üzere 3 adet örnek avlak alanı; 5 adet özel avlak alanı ve 3 adet yaban hayvanı yerleştirme sahası belirlenmiştir. İl genelinde 2 alanda ise av yasağı uygulanmaktadır. Ayrıca Ayvacık İlçesi'nde keklik (Alectoris Chukar), avlamak yasaktır. 
Tablo 1. Çanakkale av sahaları listesi

\begin{tabular}{|c|}
\hline \\
\hline $\begin{array}{l}\text { 1. Çanakkale savaşları Gelibolu Tarihi Alan Başkanlığı } \\
2 . \quad \text { Can İlcesi }\end{array}$ \\
\hline Çanakkale İlinde Devlet/Genel Avlaklar \\
\hline 1. Ayvacık ilçesi baharlar devlet avlağı \\
\hline 2. Ayvacık genel avlağı \\
\hline 3. Gülpınar devlet avlağı \\
\hline 4. Küçükkuyu genel avlağı \\
\hline 5. Bayramiç ilçesi Bayramiç genel avlağı \\
\hline 6. İkizce devlet avlağı \\
\hline 7. Kayalı devlet avlağ 1 \\
\hline 8. Bayramiç ilçesi Kazdağı devlet avlağ1 \\
\hline 9. Kumludüz devlet avlağı \\
\hline 10. Biga kırkgeçit devlet avlağı \\
\hline 11. Karabiga devlet avlağı \\
\hline 12. Danişment genel avlaği \\
\hline 13. Yeniçiftlik genel avlaği \\
\hline 14. Bozcaada genel avlağ \\
\hline 15. Çan ilçesi Karadağ devlet avlağ \\
\hline 16. Kızılelma devlet avlağı \\
\hline 17. Çan merkez genel avlağ 1 \\
\hline 18. Uzunalan genel avlağı \\
\hline 19. Eceabat ilçesi beşyol devlet avlağ 1 \\
\hline 20. Ezine ilçesi Akköy devlet avlağı \\
\hline 21. Ezine genel avlağı \\
\hline 22. Geyikli genel avlağ 1 \\
\hline 23. Gelibolu ilçesi Ilgardere devlet avlağ1 \\
\hline 24. Şadıllı devlet avlağ1 \\
\hline 25. Gelibolu genel avlağı \\
\hline 26. Gökçeada ilçesi Gökçeada devlet avlağı \\
\hline 27. Lapseki ilçesi Nusretiye devlet avlağ 1 \\
\hline 28. Üçpınar devlet avlağ 1 \\
\hline 29. Lapseki genel avlağ1 \\
\hline 30. Merkez ilçe Elmacık devlet avlağg \\
\hline 31. Kirazlı devlet avlağ 1 \\
\hline 32. Çanakkale merkez genel avlağı \\
\hline 33. Yenice ilçesi Kalkım devlet avlağg \\
\hline 34. Namazgah devlet avlaği \\
\hline 35. Poyrazköy devlet avlağı \\
\hline 36. Davutköy genel avlağı \\
\hline Örnek Avlak \\
\hline 1. Kalkım Örnek Avlağı \\
\hline 2. Gökçeada örnek avlağı \\
\hline Yabani Hayvan Yerleştirildiği İçin Avın Yasaklandığı Sahalar \\
\hline 1. Merkez ilçe Erenköy yaban hayvanı yerleştirme sahası \\
\hline 2. Merkez ilçe Saraycık yaban hayvanı (keklik) yerleștirme sahası \\
\hline 3. Akçalı yaban hayvanı yerleştirme sahası \\
\hline
\end{tabular}

Kaynak: 15 sayılı MAK Kararı

Çanakkale İli Avcılar Derneğinde kayıtlı 513 avcı ve 874 ruhsatlı av tüfeği bulunmaktadır. Ancak avcılardan alınan bilgilere göre bir o kadar da kaçak avcı il genelinde avcılık faaliyetlerinde bulunmaktadır.

Merkez Av Komisyonunun 2016-2017 Av Dönemi için aldığ1 17.05.2016 tarihinde Resmi Gazete'de yayımlanan 15 No'lu kararına göre av kuşları 4 gruba, av memelileri 2 gruba ayrılmıştır. Çanakkale ili 
söz konusu karara göre Ege Avlanma Bölgesine dahildir. Karara göre Çanakkale ilinde Ayvacık ilçesinde keklik (Alectoris Chukar), avı yasaklanmıştır.

Avlanma süreleri aynı olan kuşlar ve memeliler aynı grup içerisinde yer almaktadır. Buna göre

I. Grup Kuşlar: Bıldırcın (Coturnix coturnix) ve üveyik (Streptopelia turtur);

II. Grup Kuşlar: Kum kekliği (Ammoperdix griseogularis), kınalı keklik (Alectoris Chukar), çil keklik (Perdix perdix);

III. Grup Kuşlar: Sakarmeke (Fulica atra), sakarca (Anser albifrons), yeşilbaş (Anas platyhynchos), boz ördek (Anas strepera), çamurcun (Anas crecca), macar ördeği (Netta rufina), tepeli patka (Aythya fuligula), kılkuyruk (Anas acuta), elmabaş patka (Aythya ferina), çıkrıkçın suçulluğu (Scolopax rusticola), kaya güvercini (Columba livia), tahtal, karatavuk (Turdus merula), öter ardıç (Juniperus Sp L), boz kaz (Anser anser), kaşıkgaga (Anas clypeata) ve çulluk (Scolopax rusticola);

IV. Grup Kuşlar: Alakarga (Garrulus glandarius), küçük karga (Coloeus monedula), ekin kargası (Corvus frugilegus), leş kargası (Corvus cornix) ve saksağan (Pica pika) olarak belirlenmiştir.

Memeliler için oluşturulan gruplarda ise

I. Grup Memelilerde: Yabani tavşan (Lepus europaeus), ada tavşanı (Oryctolagus cuniculus L.), tilki (Vulpes vulpes) ve kaya sansarı (Martes fiona),

II. Grup Memelilerde: Yaban domuzu (Sus scrofa) ve çakal (Canis aureus) yer almaktadır. Belirtilen türlerin av sezonu Tablo 2'de verilmiştir.

Tablo 2: Çanakkale için 2016-2017 av sezonları

\begin{tabular}{|l|l|l|}
\hline Av Grupları & Av Süreleri (Başlangıç) & Av Süreleri (Bitiş) \\
\hline I.Grup Kuşlar & 13.08 .2016 & 15.01 .2017 \\
\hline II.Grup Kuşlar & 15.10 .2016 & 08.01 .2017 \\
\hline III.Grup Kuşlar & 15.10 .2016 & 26.02 .2017 \\
\hline IV.Grup Kuşlar & 13.08 .2016 & 26.02 .2017 \\
\hline I.Grup Memeliler & 15.10 .2016 & 08.01 .2017 \\
\hline II.Grup Memeliler & 13.08 .2016 & 26.02 .2017 \\
\hline
\end{tabular}

Kaynak: 15 Sayılı MAK Kararı

Belirtilen avlanma süreleri içinde çarşamba, cumartesi, pazar ve resmi tatillerde (idari tatiller dahil) avlanmak serbesttir. Bunun yanında üveyik (Streptopelia turtur), bıldırcın (Coturnix coturnix) ve yaban domuzu (Sus scrofa), avı belirtilen günlere ek salı günleri de serbesttir (15 sayılı MAK kararı 2. Madde 2. bent).

Çanakkale İlinde yapılan en erken avc1lık faaliyetleri 22.08.2020 tarihinde başlar ve 15.11.2020 tarihinde gün doğumundan 1 saat önce ve gün batımından 1 saat sonrasını kapsayacak şekilde olmak üzere en geç avcılık faaliyetleri biter (MAK, 2020). 4. Grup kuşlar ve 2. Grup memelilerin avlanma sezonları en uzun sezonlarken, 3. Grup kuşlar ve 1. Grup memeliler en kısa avlanma sezonlarına sahip hayvanlar olarak karşımıza çıkmaktadır. Bunları Tablo 3' te vermek mümkündür:

Tablo 3: Av hayvanları için avcı başına günlük limitler

\begin{tabular}{|l|l|}
\hline KUŞLAR & Avlanma Limiti \\
\hline Bildırcın & 10 \\
\hline Üveyik & 8 \\
\hline Karatavuk, öter ardıç, tahtalı, sakarca & 3 'er \\
\hline Kaya güvercini & 6 \\
\hline Çulluk & 5 \\
\hline Saksağan & 15 \\
\hline Bozkaz & 2 \\
\hline Sakarmeke & 4 \\
\hline Alakarga, suçulluğu & 1 'er \\
\hline
\end{tabular}




\begin{tabular}{|l|l|}
\hline Kınalı keklik ve kum kekliği & Toplamda 2 \\
\hline $\begin{array}{l}\text { Yeşilbaş, boz ördek, fiyu, çamurcun, macar ördeği, tepeli patka, elmabaş } \\
\text { patka, kaşıkgaga ve çıkrkçın (toplam limit içinde sadece 1 tanesi } \\
\text { k1lkuyruk olabilir) }\end{array}$ & Toplamda 6 \\
\hline Küçük karga, ekin kargası, leş kargası & 15 \\
\hline Serçe ve kızıl sırtlı örümcek kuşu & Y1lda Toplam 6 \\
\hline MEMELİLER & Avlanma Limiti \\
\hline Yabani tavşan (Lepus europaeus & 1 \\
\hline Ada tavşanı (Oryctolagus cuniculus L.) & 2 \\
\hline Yaban domuzu (Sus scrofa), (bek ve yürüyüş avında avcı başına) & 2 \\
\hline Kaya sansarı (Martes fiona) & 2 \\
\hline $\begin{array}{l}\text { Yaban domuzu (Sus scrofa), (sürek avında avcı başına) (sürekçiler av av } \\
\text { yapamaz) }\end{array}$ & 2 \\
\hline Çakal (Canis aureus) & 1 \\
\hline Tilki & 2 \\
\hline
\end{tabular}

Kaynak: 15 Nolu MAK Kararı, Madde 4

2016-2017 döneminde karga türleri (alakarga - Garrulus glandarius hariç) ve saksağan (Pica pika) avlanma limiti en yüksek olan av hayvanları olarak karşımıza çıkmaktadır. Limitin yüksek tutulmasına gerekçe olarak tür popülasyonunun yüksek olması ve ekinlere zarar vermeleri gösterilebilir. Alakarga (Garrulus glandarius) ve suçulluk (Scolopax rusticola), ise popülasyonun düşük olması nedeniyle az sayıda avlanabilecek kuşlardır. Bunun yanında memeli av hayvanları için maksimum limitin 2 olarak belirlenmesi, bu hayvanların doğada daha yavaş üremesi ve popülasyonlarının düşük olması nedeniyledir (Tablo 3).

\section{SONUÇ ve ÖNERILER}

Çanakkale ili bulunduğu, konum, sahip olduğu iklim ve bitki örtüsü ve topografya yüzeyinin çeşitliliği sayesinde çok farklı av hayvanlarına ev sahipliği yapmaktadır. İlin Marmara geçiş iklimi kıyı kesimlerinde Akdeniz iklim özellikleri (Atalay, 2011) göstermesi bitki örtüsünün çeşitlenmesine yol açmıştır. Bunun bir sonucu olarak il topraklarının \% 54'ü ormanlarla kaplıdır. Bu durum yörede yaşayan yaban hayvanlarının çeşitlenmesine de yol açmıştır (Atalay ve Efe 2015). İl aynı zamanda Avrupa, Asya ve Afrika kıtaları arasındaki kuş göç yolları üzerinde yer almaktadır. Nitekim il ülkemizdeki kuş türlerinin yarıdan fazlasına $(\% 58)$ ev sahipliği yapmaktadır (Tarım ve Orman II. Bölge Müdürlüğü Çanakkale Şube Müd., 2019). Bütün bu özelliklerin bir araya gelmesiyle Çanakkale ili kendine özgü yaban hayatı ve bol miktarda av hayvanına ev sahipliği yapmaktadır.

İlde bulunan 36 adet avlak (devlet avlakları, genel avlaklar, özel ve örnek avlak) avcılık sporunun yaygın olarak yapıldığı alanları barındırmaktadır. İlde ikamet eden 513 kayıtlı avcı ve diğer çok sayıda avcının yanı sıra il dışından gelen çok sayıda avcı avlanmak için ili (özellikle Kaz dağlarını) tercih etmektedir. Ağustos ayında av sezonu açılınca en çok rağbet gören avlar çulluk (yelve) (Scolopax rusticola), bıldırcın (Coturnix coturnix), tahtalı (büyük üveyik - Columba palumbus) ve üveyik (Streptopelia turtur) avıdır. Domuz (Sus scrofa), avı tarladaki mahsule çok zarar vermesi nedeniyle özendirilen bir avdır. Domuz aynı zamanda aşırı ürediğinden IUCN'nin 1996 “Kırmızı Listesi”ne göre LC: (Asgari endişe) grubunda yer almaktadır. Özellikle son yıllarda kırsaldan kente göç bağlı olarak oluşan kırsaldaki avcı azalması nedeniyle aşırı popülasyonu aşırı artmıştır. Öyle ki domuz sürüleri insanların yaşam alanına kadar yiyecek arama için gelmektedirler.

Çanakkale'de avcılığın yoğun yapılması ve kaçak avcılığın getirdiği sorunlar il genelindeki yaban hayatını tehdit etmektedir. Bu tehditlerin ortadan kaldırılması için denetimlerin sıklaştırılması, sezon dışı avcılık ve her türlü yasa dışı avcılıkların önlenmesi önemlidir. Maalesef il genelinde kaçak avcılık faaliyetleri hala devam ederek tür popülasyonları ve çeşitliliği tehdit altındadır. Özellikle keklik (Perdix perdix), çulluk (yelve) (Scolopax rusticola), bıldırcın (Coturnix coturnix), tahtalı (büyük üveyik -Columba Palumbus), üveyik (Streptopelia turtur) tavşan (Lepus europaeus), yelve (Emberiza clrlus), geyik (Cervus elaphus), karacanın (Capreolus capreolus) olumsuz etkilendiği bilinmektedir. 
Yasa dışı avcılık ve diğer sorunların Çanakkale yabani av hayvan varlığı üzerinde yaptığı bu baskıyı hafifletmek ve kalıcı önlemlerin alınmasını sağlamak için aşağıdaki çözüm önerileri sunulabilir:

1. İl genelinde av hayvanları üretme çiftlikleri kurularak av hayvanı popülasyonlarının tekrar artırılması sağlanmalıdır.

2. İl genelindeki avlanmaya yasak bölgeler genişletilerek sayı ve alan olarak artırılmalidır.

3. Yasa dışı avlanan kişiler ise avcılığın ve av hayvanlarının sürdürülebilirliğini en fazla zararı vermektedir. Yasa dışı avcılık faaliyetlerine karşı denetimler sıklaştırılmalı, söz konusu kişilere caydırıcı yaptırımlar uygulanmalıdır.

4. Av kotalarının aşılmamasına ve sezon dışı avcılığın tamamen ortadan kaldırılmasına yönelik önlemler artırılmalıdır.

5. Avcılar eğitilerek doğayı korumayı ve sevmeyi öğrenmeli, silah kullanımında kurallara harfiyen uymayı alışkanlık haline getirmelidir. İyi bir avcı ruhsatsız silah ile avlanmamalı, avlanma kurallarına ve avlanma süresine riayet etmeli, av sonu silahı boşaltmalı, silahla asla şaka yapmamalı, hamile olduğunu anladığı ava ateş etmemeli, yaralı hayvana eziyet etmemeli, asla gece 1şıkla av yapmamalıdır (Güngör ve diğ., 2014).

6. Av hayvanı olmayan veya koruma altına alınarak avlanması yasak olan hayvanları avlayanlar hakkında para cezasının yanında hapis cezaları da uygulanarak cezaların yaptırım güçleri artırılmalıdır.

7. Avcılar arasında dayanışma sağlanarak birbirlerini uyarmaları sağlanmalı bu şekilde avcılık sporuyla ilgilenenler arasında bir iç denetim mekanizması kurulmalıdır.

8. Avcılık eğitimine önem verilmelidir. Kayıtlı 874 adet ruhsatlı av tüfeği potansiyel tehlikedir. Ülkemizde 2005 yılından bu yana açılan avcılık kurslarında sürdürülebilir avcıllığın eğitimi verilmekte ve avcılar bilinçlendirilmektedir. Ancak bu eğitimlere maalesef sadece avc1lık belgesi olan yani av yapma izni olan avcılar katılmaktadır. Kayıtsız avcılar av ve yaban hayatına zarar vermeye devam etmektedirler.

Bilgilendirme / Acknowledgement:

1- Makalemizde etik kurulu izni ve/veya yasal/özel izin alınmasını gerektiren bir durum yoktur.

2- Bu makalede araştırma ve yayın etiğine uyulmuştur.

\section{KAYNAKÇA / REFERENCES}

Atalay, İ. (2011). Türkiye coğrafyası ve jeopolitiği. İzmir: Meta Basımevi.

Atalay, İ. ve Efe, R. (2015). Türkiye biyocoğrafyası. İzmir: Meta Basımevi.

Büyükarıkan, U. (2018). Avc1 ölçeği ile Türkiye'de avcı profilinin analizi. Turkish Journal of Forestry, 19(2), 163-169.

Becercan, M.T. (2010). Türk dili ve kültürü açısından Baburname'de avcıllı. Atatürk Üniversitesi Türkiyat Araştırmaları Enstitüsü Dergisi, 17(42), 11-34.

Cahoone, L. (2009). Hunting as a moral good. Environmental Values, 18(1), 67-89

Celilova, A. (2019). Avcılık inanç ve ritüellerine bakış. Sosyal Araştırmalar ve Davranış Bilimleri Dergisi, 5(8), s.62-86

Çalışkan V., Tosunoğlu M., Öztürk M.Z., Samsa Ş., Arslan F., Bay A., (2013). Çanakkale için bir tabiat parkı önerisi çardak kıyı oku ve lagünü (Çardak Kuş Cenneti). Çanakkale: Arüv Çevre Müh. Müş. Hiz. san. Tiç. Ltd. Şti. 
Çaya, S. (2015). Türkler'de avcılık. Türk ve İslam Dünyası Sosyal Araştırmacılar Dergisi, 2(3), 86-95.

Davison, M. W. Eds: (1999). Ne zaman, nerede, neden, nasıl oldu. Dünya Tarihi Kitapları (1). USA: Reader's Digest.

Demirsoy, A. (2007). Genel zoocoğrafya ve Türkiye zoocoğrafyası / Hayvan Coğrafyası. Ankara: Meteksan.

Dillinger J. (2012). Treasure hunters magic. 1n: magical treasure hunting in Europe and North America. Palgrave Historical Studies in Witchcraft and Magic. London: Palgrave Macmillan.

Güven, Ö. ve Hergüner, G. (1999). Türk kültüründe avcıllı̆ın temel dayanakları. Pamukkale Üniversitesi Eğitim Fakültesi Dergisi, 5(5), 32-49.

Doğa Koruma ve Milli Parklar Genel Müdürlügü. Avına İzin Verilen Yaban Hayvanları, (e-kitap). 30 Mayıs 2017 tarihinde www.milliparklar.gov.tr/kitap/64 adresinden erişildi.

Doğa Koruma ve Milli Parklar Genel Müdürlüğü. Biyolojik çeşitlilik ile ilgili sivil toplum kuruluşlarının kapasitesinin arttırılması için strateji ve eylem planı (e-kitap). 06 Mayıs 2017 tarihinde www.milliparklar.gov.tr/kitap/73 adresinden erişildi.

Doğa Koruma ve Milli Parklar Genel Müdürlüğü. Doğa koruma raporu (2002-2013) (e-kitap). ) 06 Mayıs 2017 tarihinde www.milliparklar.gov.tr/kitap/90 adresinden erişildi.

Doğa Koruma ve Milli Parklar Genel Müdürlüğü. Türkiye'de av ve yaban hayatı, (e-kitap). 04 Mayıs 2017 tarihinde www.milliparklar.gov.tr/kitap/77 adresinden erişildi.

Doğa Koruma ve Milli Parklar Genel Müdürlüğü. Türkiye korunan alanlar yönetim planlaması rehberi, (e-kitap). 04 Mays 2017 tarihinde www.milliparklar.gov.tr/kitap/72 adresinden erișildi.

Doğa Koruma ve Milli Parklar Genel Müdürlüğü. Türkiye'nin kuşları (kuş kartları) (e-kitap). 04 Mayıs 2017 tarihinde www.milliparklar.gov.tr/kitap/9 adresinden erişildi.

Doğa Koruma ve Milli Parklar Genel Müdürlüğü. Türkiye'nin önemli sulak alanları (Ramsar alanlarımız) (e-kitap). 04 Mayıs 2017 tarihinde www.milliparklar.gov.tr/kitap/7 adresinden erişildi.

Erol, O (1985). Çanakkale yöresi güney kesiminin jeomorfolojisi. Jeomorfoloji Dergisi, 4, 1-7

Güngör, Y., Çinar N., Uslu B., Çiftçi E. (2014). Sinop bölgesinde av ve avcılık. Karadeniz Uluslararası Bilimsel Dergi, 1(22) , 81-93

Gürpınar, E. (1988). Çevre hukukunda 'ekolojik denge' kavramı ve bu dengenin korunması. Yayımlanmamış yüksek lisans tezi, İstanbul Üniversitesi, İstanbul.

http://www.canakkale.com.tr/tr/sehri-yasa/flora-fauna. 31 Mayıs 2017 tarihinde erişildi.

Ilgar, R. (2017). Çanakkale ilinde tarımda sürdürülebilirlik ve organik tarım. Doğu Coğrafya Dergisi, $37,159-178$.

Ilgar, R. (2018). Ekoloji ve çevre araştırmaları. Bursa: Ekin Yayınevi.

Kantarc1, D., (1997). Biga yarımadasında ekolojik faktörler ile ağaç ve çalı türlerinin yayılışı arasindaki ilişkiler ve ormanlara zarar verebilecek etkenler, yerleşim ve çevre sorunları: Çanakkale Illi, 9-13 Eylül 1996, Bildirileri, İzmir.

Kaya, M. (2009). Dede Korkut kitabı ve Manas Destanı'nda Av. Acta Turcica Çevrimiçi Tematik Türkoloji Dergisi, 1, 96-106.

MAK (Merkez Av Komisyonu) (2016). 2016-2017 av dönemi merkez av komisyonu kararı. Ankara: T.C. Çevre ve Orman Bakanlığı Doğa Koruma ve Milli Parklar Genel Müdürlügü.

MAK (Merkez Av Komisyonu) (2020). 2020-2021 av dönemi merkez av komisyonu kararı. 12 Ağustos 2020 Tarihli Resmi Gazete, 31211 (Mükerrer). 
Oğurlu, İ. (2008). Yaban hayatı kaynaklarımızın yönetimi üzerine. Süleyman Demirel Üniversitesi Orman Fakültesi Dergisi, 2, 35-88.

Onay, İ. (2015). İslam öncesi Türk kültüründe avcıllğın temelleri ve iktisadi, askeri, dini değeri, Journal of International Social Research, 41, 516-525.

Özer, O. (2020). Türkiye'nin av turizmi potansiyeli konusunda bir değerlendirme. Journal of Gastronomy, Hospitality and Travel, 3(1), 71-86

Potapov, L .P. (2012). Altay Türklerinde avcı inançları ve gelenekleri. (Çev Bağci A.), Karadeniz Uluslararast Bilimsel Dergi, 1(15). 30 Ağustos 2020 tarihinde https://dergipark.org.tr/tr/download/article-file/155330 adresinden erişildi.

Siyako, M., Bürkan, K.A. ve Okay, A.İ., (1989). Biga ve Gelibolu Yarımadaları'nın tersiyer jeolojisi ve hidrokarbon olanakları. TPJD Bülteni, 1(3), 183-199.

Şahin, S. (2006). Türkiye'nin nüfus gelişimde bölgesel farkllllklar. Avrupa Birliği sürecindeki Türkiye'de bölgesel farklılıklar. Ankara.

T.C. Tarım ve Orman Bakanlığı Çanakkale İl Müdürlüğü (2019). Yılı Brifing Dosyasından 10 Temmuz 2020 tarihinde (https://canakkale.tarim.gov.tr/Menu/13/Brifingler) adresinden erişildi.

T.C. Tarım ve Orman II. Bölge Müdürlüğü Çanakkale Şube Müdürlüğü (2019). Çanakkale İli 2018 Yılı Çevre Durum Raporu. 30 Ağustos 2020 tarihinde (https://webdosya.csb.gov.tr/db/ced/icerikler/canakkale_-cdr2018-20200123080146.pdf) adresinden erișildi.

TUIK (2019). Kimyasal gübre kullanımı istatistikleri: 2009-2019. 30 Ağustos 2020 tarihinde tuik.gov.tr/PreIstatistikTablo.do?istab_id=2287 adresinden erișildi.

Turan, L.S. (1992). Türkiye'de kuluçkaya yatan bıldırcın ( Coturnix coturnix coturnix Linne, 1758) populasyonları ile ilgili biyo- etolojik araştırmalar. Yayımlanmamış doktora tezi, Hacettepe Üniversitesi, Ankara.

Ünal, Y. (2019). Yaban hayvanı türleri ve yaşama ortamları üzerindeki kısıtlayıcı faktörler. MAS International European Conferenceon Mathematics-Engineering-Naturalmedical Sciences-X Bildirileri, Aral1k 14-15, İzmir, 261-268.

Yarci, G. (2009). Osmanlı'da avcılık yasaları. Acta Turcica Çevrimiçi Tematik Türkoloji Dergisi, $1(1), 123-152$. 